\title{
Till MUSEETS GENEALOGI
}

"En god museiman är en person med ett gott öga" (a man with an eye) skriver David M Wilson i sin lilla bok om British Museum (1989). Han träffar säkert rätt. Det väsentliga i museets meddelanden till det omgivande samhället är grundat på synligheter; ur det synliga härleds museets tolkningar och budskap. I det uppvisade och utställda framläggs bevisen som skall övertyga betraktaren om budskapets giltighet. Men seendet har en historia. Perceptionens villkor påverkas av förändringar i de diskurser och paradigmförskjutningar som styr vår uppfattningsförmåga, våra föreställningar och världsbilder. Museets samlande och utställningar blir därigenom en fortlöpande och instruktiv spegel av tankeformernas förändringar i västvärlden.

Det var därför en särdeles givande analytisk utgångspunkt som valts för det danska Nationalmuseets stora utställning Museum Europa, där det museala seendet gjorts till grundtema. Utställningen synliggjorde fyra grundtyper: det kuriøse, det spejlende, det panoramiske, det surreale blik. Genom studier i norra Europas äldsta samlingar och i avbildningar av deras exponering vid olika tidpunkter formades utställningsplanen av utställningsgruppen under Annesofie Beckers ledning. Tack vare att ett rikt urval ur dessa samlingar varit möjligt att låna gav utställningen en unik och fantasieggande dokumentation av det museala seendets former.

Tematiken avtecknade sig i en expressiv scenografi med de skilda utställningsdelarna infattade i stiliserade, associativa sättstycken.

Museum Europa kan med fördel ses som ett kvalificerat museologiskt forskningsprojekt som givits en adekvat visuell redovisningsform - en utställning. Sedan den nu avslutats i Köpenhamn, kommer den att hösten 1994 visas i Bonn.

Men tankestrukturen i utställningen finns också textmässigt redovisad i en vacker katalog där bl.a. de välformulerade introduktionstexterna till utställningens avdelningar återges. I projektet ingår även en videokassett med sex korta beskrivningar av besök i Urmuseum, Dresden, Museo del Costume e delle Arti Popolari, Nuori, Sir John Soane's House and Museum, London, La Specola, Firenze, 
NORDISK MUSEOLOGI $1993 \cdot 2$

Museum des Institutes für Geschichte der Medizin, Wien och The Pitt Rivers Museum, Oxford (se vidare s. 111).

Utställningen gav anledning till ett specialnummer av Den jyske Historiker (64/1993) - 'Museum Europa. Om tingenes orden' - som det finns goda skäl för den museologiskt intresserade att ta del av. Det innehåller uppsatser av danskarna Jens Erik Kristensen, Carsten Thau, Jörgen Jensen, Frederik Stjernfelt, Inger Sjörslev; norrmannen Arnfinn Bø-Rygg, svenskarna Ingela Lind och Sverker Sörlin samt Krzysztof Pomian, Paris, Hermann Lübbe, Zürich, G W von Leibniz (med kommentar av Arno V Nielsen), Walter Grasskamp, Aachen, och MarieLouise von Plessen, Berlin. Filosofen Arno Victor Nielsen har redigerat och skrivit en sammanhållande inledning.

Symposiet Till museets genealogi, 23-25 september 1993, organiserat av Nationalmuseet i samarbete med museologiska institutionen i Umeå, hade utställningen som självklar och näraliggande referens. De texter som publiceras i detta nummer av tidskriften presenterades som bidrag till symposiet - med två undantag. Holger Rasmussens om Bernhard Olsen ingick i Museumshöjskolens föreläsningsserie, varur tre bidrag fanns med i föregående nummer. Susan Pearce var förhindrad att deltaga i symposiet, men har bidragit i efterhand.

Alla bidragen till museets genealogi får dessvärre inte plats. Texter av bl a Walter Grasskamp, Marie-Louise von Plessen, Beat Wyss, Bjørnar Olsen och Sverker Sörlin hoppas vi få tillfälle att återge i ett kommande nummer.

Första årgången av Nordisk Museologi som nu - med viss fördröjning - föreligger komplett, har kunnat utges tack vare ekonomiskt stöd av Nordisk Kulturfond, Museumshöjskolen och Norsk Museumsutvikling.

$$
\text { Per-Uno Ågren }
$$

\footnotetext{
Museet og al dets vesen er $i$ disse år pludselig blevet genstand for stor teoretisk interesse bland filosoffer, kulturbistorikere, kulturjournalister og sågar blandt museumsfolk. Det er som om museet pludselig har tabt sin uskyld, sin selvfolgelighed. Hvad er det egentlig vi gor, når vi fylder et skab, en montre, et rum, flere rum, eller en hel bygning op med ting og sager och kalder det et museum? Den slags sporgsmal udtrykker, hvad man med et fint ord kalder en metabevidsthed om museeet. Den er forudsatningen for, at der kan opsta en egentlig teori - logos - om museet, altsa ren museologi.

(Arno Victor Nielsen i 'Den jyske Historier', 64/1993)
} 